Journal of Environmental Sciences
JOESE 5
ISSN 2090-9233
Journal homepage http://Joese.mans.edu.eg

Original Article

\title{
Occurrence of Carnotite in the Phosphatic horizon of the Sudr Chalk, Wadi El-Quseiyib, East Central Sinai, Egypt: Paleoenvironmental and Radioactivity Implications
}

\author{
Amin M. Gheith ${ }^{1}$, Mohamed M. El Sankary ${ }^{2}$, Tarek I. Anan ${ }^{1}$ and Asmaa S. Ibrahim ${ }^{1}$ \\ ${ }^{1}$ Department of Geology, Faculty of Science, Mansoura University, Mansoura, Egypt \\ ${ }^{2}$ Nuclear Materials Authority, El Maadi, Cairo, Egypt
}

\begin{tabular}{|c|c|}
\hline Article Info & Abstract \\
\hline $\begin{array}{l}\text { Article history : } \\
\text { Received } \\
\text { Received in revised } \\
\text { form } \\
\text { Accepted }\end{array}$ & $\begin{array}{l}\text { Anomalous uranium contents were recognized in the phosphatic beds of the Campanian- } \\
\text { Maastrichtian Sudr Chalk of Wadi El-Quseiyib at the East Central Sinai. Microscopic examination, } \\
\text { and scanning electron microscopy revealed the presence of carnotite patches disseminated in the } \\
\text { studied Sudr Chalk phosphatic rocks. This mineral is recorded for the first time in the east central } \\
\text { Sinai and it may be significant in discussing uranium prospection and the origin of secondary uranium } \\
\text { deposits. The identification of this mineral directed the attention to study the natural radionuclides }\end{array}$ \\
\hline $\begin{array}{l}\text { Keywords: } \\
\text { Sudr Chalk } \\
\text { phosphate } \\
\text { Carnotite } \\
\text { Uranium } \\
\text { Vanadium } \\
\text { SEM/EDX } \\
\text { HPGe } \\
\text { Sinai } \\
\text { Egypt }\end{array}$ & $\begin{array}{l}\text { content which have been measured by gamma-ray spectrometry using a shielded HPGe detector. This } \\
\text { study revealed that }{ }^{238} \mathrm{U} \text { and some of its progenies were redistributed after subjection to several } \\
\text { alteration processes. } \\
\text { Petrographic study of Wadi El-Quseiyib phosphatic rocks revealed that they are consisted mainly } \\
\text { of collophane pellets, bone and teeth fragments, which were diagenetically cemented by calcite, } \\
\text { gypsum and quartz materials. The studied phosphatic microfacies was described texturally as } \\
\text { pelphospharudite and pelphospharenite. X-ray diffraction analysis proved the presence of carbonate } \\
\text { fluorapatite (francolite) as the dominant phosphatic mineral, while calcite, gypsum and quartz are the } \\
\text { dominant non-phosphatic minerals with minor contents of bassanite and jarosite and siderotil. } \\
\text { Averages of } \mathrm{P}_{2} \mathrm{O}_{5} \text { and uranium contents are } 16.7 \% \text { and } 70 \mathrm{ppm} \text { in the analyzed phosphatic rocks, } \\
\text { respectively. Carnotite characteristics are identified by SEM/EDX in the studied phosphatic rocks } \\
\text { which indicate that the uranium is leached out from the phosphatic materials and re-deposited as fine } \\
\text { specks in open pores by circulating meteoric water. The leached uranyl ions together with vanadate } \\
\text { ions are forming the identified carnotite under the influence of evaporation. The calculated annual } \\
\text { effective dose equivalent values (AEDE) are } 0.478 \text { and } 0.504 \text { mSv/yr for the lower and upper } \\
\text { phosphatic beds, respectively. The calculated radium equivalent activity values of (Ra } \mathrm{a}_{\mathrm{eq}} \text { ) are } 2319 \text { and } \\
2802 \mathrm{~Bq} / \mathrm{kg} \text { for the lower and upper phosphatic beds, respectively. Accordingly, although the } \\
\text { estimated (AEDE) to the public is below the recommended limits, but the equivalent radium activity } \\
\text { and the expected coincided radon gas emanation renders the phosphatic exposures in the study area } \\
\text { classified unsafe for prolonged public activities. }\end{array}$ \\
\hline
\end{tabular}

\section{Introduction}

Wadi El-Quseiyib is located in East Central Sinai between Latitudes $29^{\circ} 14^{\circ}-29^{\circ} 19^{\prime} \mathrm{N}$ and Longitudes $34^{\circ} 36^{\prime}-$ $34^{\circ} 45^{\prime} \mathrm{E}$ (Figs. 1 and 2). Silicified phosphatic carbonate rocks belonging to the Sudr Chalk are exposed at hillocks and mounds in the western upper catchment parts of the valley, meanwhile Precambrian basement rocks are exposed delineating the northern and southern catchment parts. The

\section{*Correspondence author:}

Tel.:

E-mail address: regional topography is uneven. General slope of the land is towards east. The climate is semi-arid to arid with winter rainfall and occasional flashfloods.

Phosphate rocks are usually enriched in uranium since phosphate and uranium tend to accumulate together (Roessler, 1990). The possible connection mechanism is most likely the incorporation of $\mathrm{U}^{4+}$ in the structural lattice of apatite substituting calcium Altschuler et al. (1958). Accumulation of decaying organic materials reduces the $\mathrm{U}^{6+}$ in sea water to $\mathrm{U}^{4+}$, facilitating its incorporation into the apatite structure. Uranyl ions could also be adsorbed on the surface of the accompanying clay minerals and iron oxihydroxides. So, 
longer period of exposure of phosphorites to sea water led to syn- to post-depositional enrichment in uranium content. Major regional controls on the distribution of surficial uranium deposits are climate, geomorphology and provenance (Carlisle, 1984).

Carnotite, a secondary uranium mineral composed of hydrated potassium uranyl vanadate $\left[\mathrm{K}_{2}\left(\mathrm{UO}_{2}\right)_{2}\left(\mathrm{VO}_{4}\right)_{2} \cdot 3 \mathrm{H}_{2} \mathrm{O}\right]$, was identified through the study of the Sudr Chalk phosphatic deposits. Carnotite is the most common hexavalent uranium phase that generally occurs in secondary ore deposits as a product of supergene alteration and oxidation of primary ores (Bowell et al., 2011). Secondary uranium minerals formed by weathering or sedimentation processes were described several decades ago, in a stratigraphically correlated Middle East phosphorites in northern Negev (Gross and Ilani, 1987; Ilani and Strull, 1989), in central Jordan (Helmdach et al., 1985; Fleurance et al., 2013) and recently in north Saudi Arabia (Khater et al., 2016). These minerals were also reported in northern Sinai at Gabal Urayf El-Nagah area by Hussein et al. (1996).

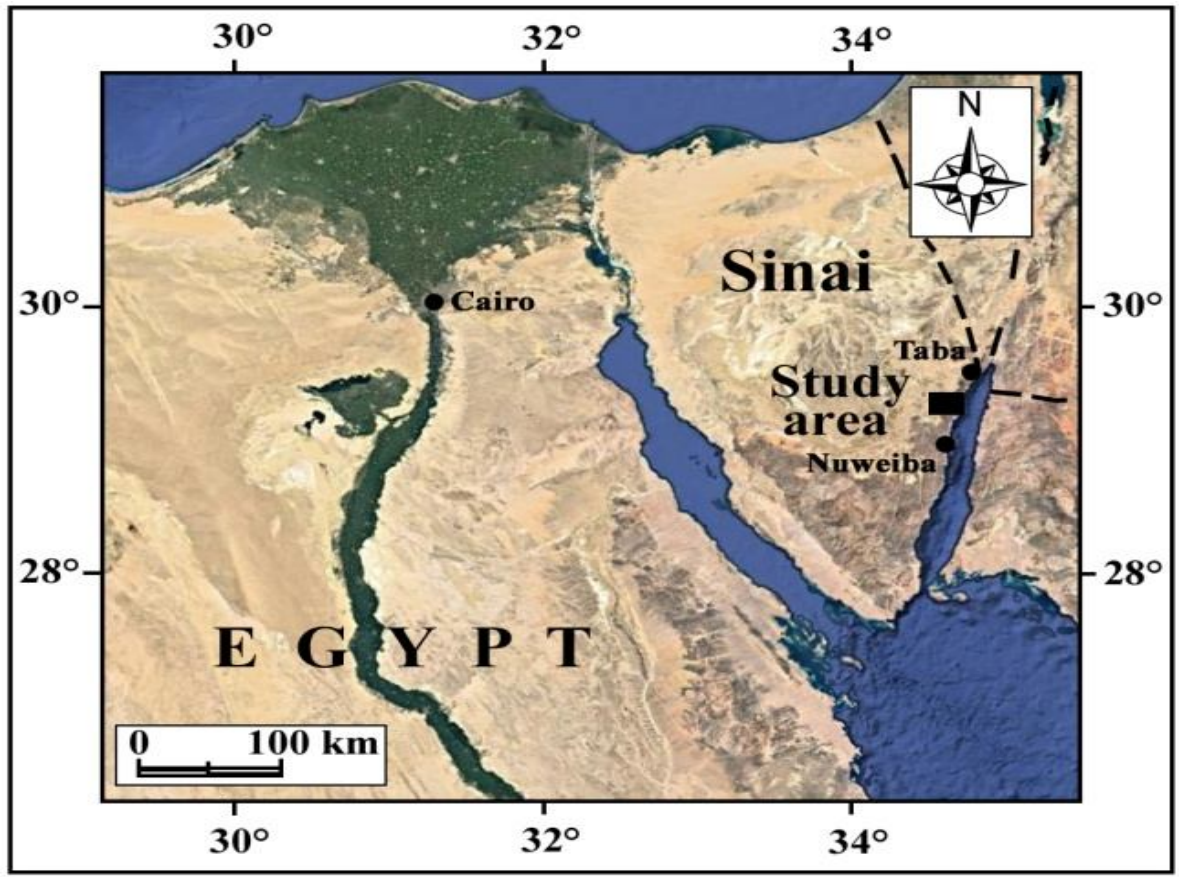

Fig. 1: Google Earth satellite image showing location of Wadi El-Quseiyib study area (the black square).

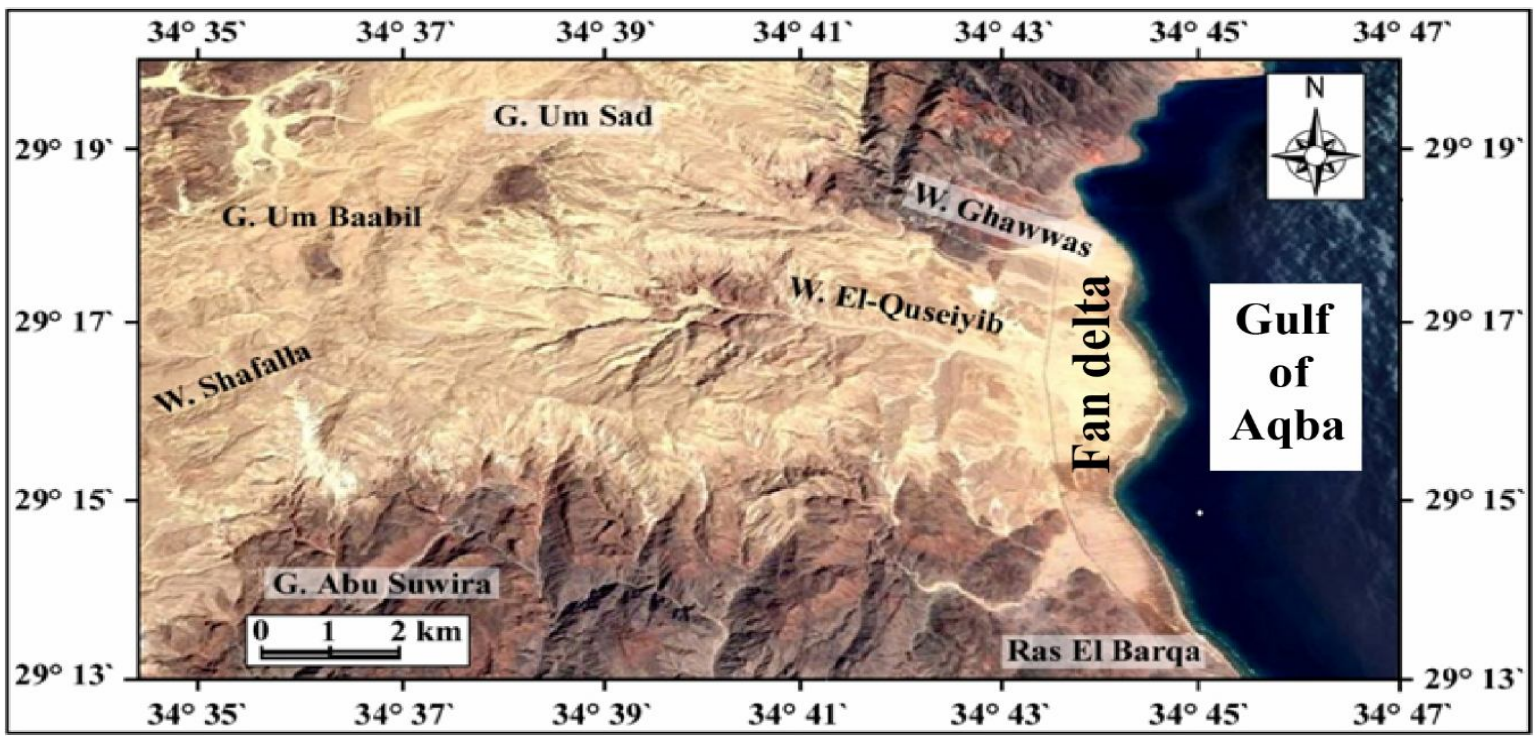

Fig. 2: Google Earth satellite image showing physiographic features of Wadi El-Quseiyib. 
The identification of uranium, always as carnotite, in several host rocks of alluvium, soil or detritus materials cemented by carbonates is considered as important recent development in uranium geology (Nash et al., 1981). The most important carnotite enriched uranium deposits are located in Western Australia (calcrete) and Namibia (calcretegypcrete). Leaching of uranium-bearing rocks, even with low uranium content, under particular erosion and weathering conditions causes the precipitation of secondary uranium minerals in downstream suitable environments (Dall'Aglio et al., 1974; Mann and Deutscher, 1978; Butt et al., 1984).

In the present study, identification and characterization of the detected carnotite in the silicified phosphatic carbonates of the Campanian- Maastrichtian Sudr Chalk were carried out. An attempt has been made herein to deduce the paleoenvironmental inferences and the mode of formation of carnotite.

\section{Geologic Setting}

The Upper Cretaceous exposures in East Central Sinai comprising Wadi El-Quseiyib study area (Figure 3) are represented by carbonate-dominated successions interbedded with few sandstone, chert, shale and marl beds (Kora and Genedi, 1995). The upper Cretaceous succession includes from base to top: the Raha Formation (Fm.), Abu Qada Fm., Wata Fm., Matulla Fm. and the Sudr Chalk. The latter is further subdivided into the lower Markha Chalk Member and the upper Abu Zenima Chalk Member (Fig. 4) as suggested by Ghorab (1961) for equivalent strata in the Gulf of Suez area. This Upper Cretaceous succession is unconformably underlain by a Lower Cretaceous continental sandstone sequence known as the Malha Fm. in the study area and unconformably overlain by the Esna Fm. of Paleocene age in the neighboring Sheikh Attia and Taba areas.

The Campanian-Maastrichtian Sudr Chalk reaches about $85 \mathrm{~m}$ in thickness in the study area and represents the main target in this study due to the presence of several phosphatebearing beds (Fig. 4). The formation is composed mainly of carbonate rocks alternating with some phosphatic and cherty interbeds. It is unconformably underlain by the ConiacianSantonian Matulla Fm. and unconformably overlain by the Paleocene-Lower Eocene Esna Fm. to the west of the study area. Moreover, some authors (e.g. El Aassy, 1992; Hussein et al., 1996; Guirgues, 2005) were informally subdivided the Sudr Chalk in East Sinai into three members according to its lithology and aerial extension. They separated the upper part of the Markha Member, measured about $8.5 \mathrm{~m}$ in the study area, as a Middle phosphate- and chert-bearing Member. This member is composed of marly limestone interbedded with chert bands and six phosphatic limestone beds varying in thickness from 30 to $60 \mathrm{~cm}$, with a total thickness reaching about $2.5 \mathrm{~m}$. These beds are greyish to brownish in color, hard to moderately hard, partly silicified, with frequent phosphatic pellets, shark teeth and bone fragments.

Concerning the environment of deposition, the Campanian-Maastrichtian sedimentation was influenced by open-marine conditions with a low sedimentation rate (Issawi et al., 1999). Deposition of marl, chalk and the associating phosphatic limestone was controlled both in thickness and facies by incipient folding of the Syrian Arc (Flexer and Honigstein, 1984). In more detail, Kora and Genedi (1995) stated that some shallow subtidal to intertidal regressive events were interrupted the prevailing open-marine conditions. Subsequently, the resulted shallowing of the sea level could have contributed to the formation of isolated basins where the phosphatic materials accumulated.

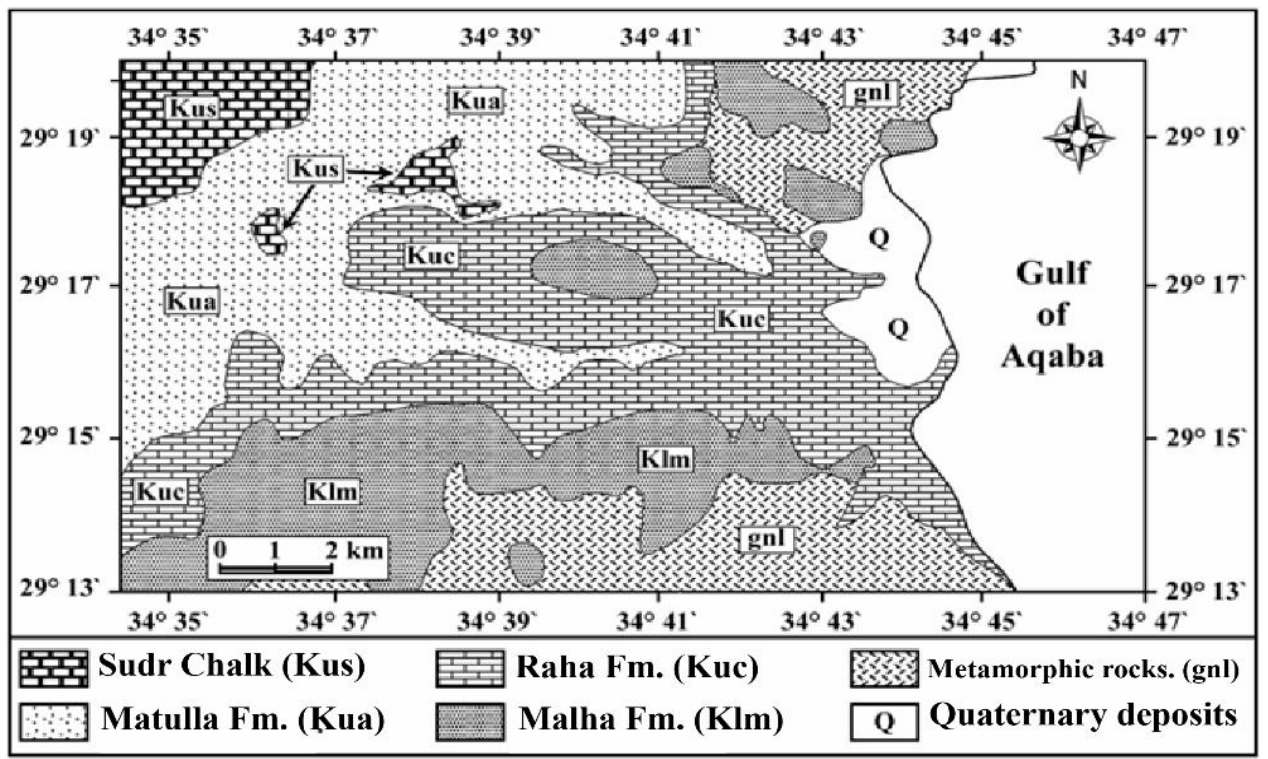

Fig. 3: Geological map for Wadi El-Quseiyib area (adapted from CONOCO and EGPC, 1987). 


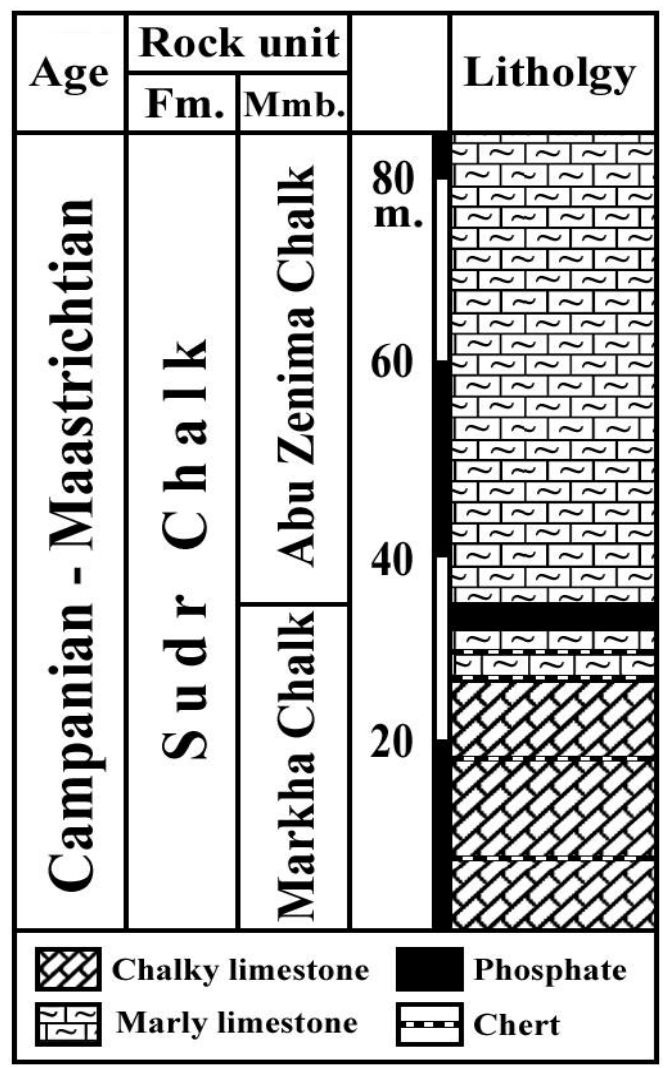

Fig. 4: Lithostratigraphic section of the Sudr Chalk at Wadi El-Quseiyib area (modified after Kora and Genedi, 1995; Guirgues, 2005).

\section{Material and Methods}

The first sample represents the lower three beds and the other represents the upper three beds. Six thin sections representing the six encountered phosphatic beds in the upper part of the Markha Member were investigated petrographically using the polarizing microscope to determine their textural characteristics and mineralogical constituents. For X-ray diffraction analysis and determination of natural radionuclides content two composite samples were prepared to represent the encountered six phosphatic beds.

The mineralogical composition of the phosphatic samples was then identified using the X-ray diffraction analysis with a unit Philips (PW-3710) diffractometer with $\mathrm{Cu}$ target tube and $\mathrm{Ni}$ filter at $40 \mathrm{kV}$ and $30 \mathrm{~mA}$. Petrographical and mineralogical studies were mainly benefited by using the environmental scanning electron microscope (ESEM) microanalysis. A Quanta 250 FEG (Field Emission Gun) attached with EDX Unit (Energy Dispersive X-ray Analyses) was used in the present study. Spot modes of EDX were performed to analyze semi-quantitatively the gross chemical composition of constituents. A backscattered electron (BSE) detector was mainly used and samples were coated using Emitech K550X sputter coater. The equipment is calibrated to make the necessary corrections by ZAF software.
Although EDX analysis of elements is semi-quantitative, careful standardization and recognition of the obtained spectrum improve the quality of the obtained data. The acquisition time was 180 seconds at $30 \mathrm{kV}$ acceleration voltages.

The two composite samples were prepared for gamma-ray spectrometric analysis by the high purity germanium detector (HPGe). This high resolution gamma-ray spectrometry system is widely used for radioactivity analysis because of its superior energy resolution with the availability of large size crystal (Chinnaesakki et al., 2012). The used detector was closed-end coaxial (n-type) made of high purity germanium (HPGe) in a vertical configuration cooled with liquid nitrogen. It has a relative efficiency of about $60 \%$ of the 3" X 3" NaI (Tl) crystal efficiency, resolution of $2.3 \mathrm{keV}$ and peak/Compton ratio of $56: 1$ at the $1.33 \mathrm{MeV}$ gamma transition of ${ }^{60} \mathrm{Co}$. Uranium concentration in the studied composite samples was also chemically determined in solution using Scintrex UA-3 laser fluorometer uranium analyzer. An intense excitation source, $\mathrm{N}_{2}$-Laser, at $337 \mathrm{~nm}$ is applied for exciting uranium. In addition, spectrophotometric determination of phosphorus as $\mathrm{P}_{2} \mathrm{O}_{5}$ was carried out using the molybdenum blue method (Vogel, 1989). 


\section{Results}

\subsection{Petrography}

Investigation of the thin sections with the petrographic microscope proved that the studied phosphatic rocks are generally consisted of phosphatic grains, non-phosphatic grains and cement and/or matrix (Fig. 5). Phosphatic grains are composed of collophane pellets of different sizes besides various skeletal bone and teeth fragments. They are imbedded in micritic to microsparitic calcite, ferruginous or microcrystalline quartz cement. Collophane (pellets) are generally structureless, rounded to subrounded, and their sizes reach up to $0.5 \mathrm{~mm}$ in diameter (Figs. $5 \mathrm{~A}$ and B). They are isotropic to translucent under crossed Nicols indicating their cryptocrystalline apatite (collophane) composition. The observed high roundness of the phosphatic pellets and nearly absence of detrital quartz grains could indicate syndepositional active hydraulic sorting by waves and strong currents.

Phosphatic bioclasts are composed of colorless transparent fragments of fish bones and less abundant fish teeth with diverse shapes and sizes (Figs.5 C and D). Post-depositional cracking and filling with microcrystalline quartz and phosphatic mud is frequently observed. According to the classification given by Slansky (1986), the recorded microfacies of the studied rocks are: pelphospharudite, pelphospharenite and phosphatic chalk. The pelphospharudite microfacies contains particles of grain size more than $2 \mathrm{~mm}$, which are mostly bone fragments, while the pelphospharenite microfacies contains peloids of sandy grain size.
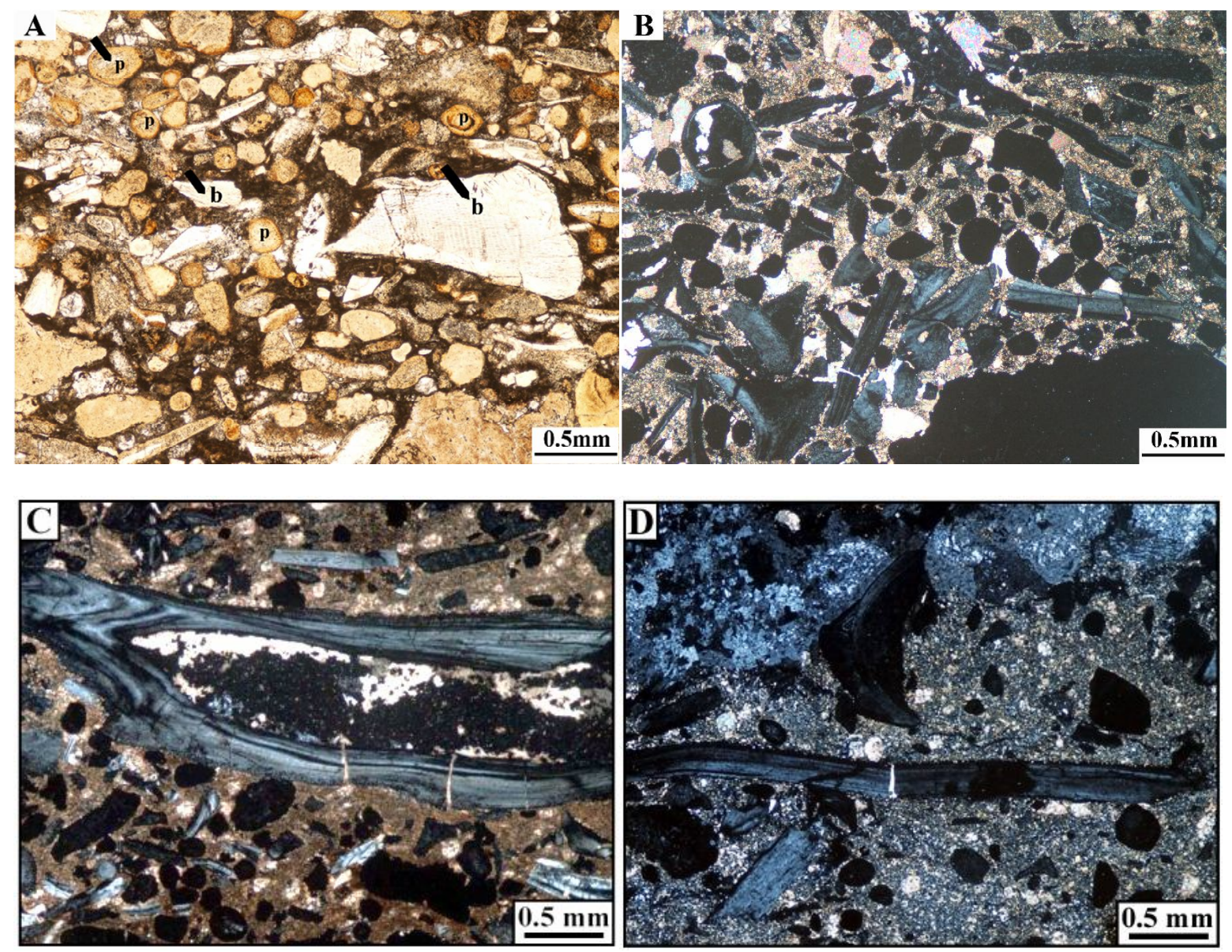

Fig. 5. Photomicrographs showing: (A) Structureless phosphatic pellets (p) and bone fragments (b) with lamellar structure embedded in ferruginous cement (PPL); (B) Opaque well-rounded collophane grains and bone fragments embedded in micritic matrix, notice the newly formed bassanite growth with high interference colors in the central upper part (XPL); (C) Phosphatic pellets and bone fragments embedded in micritic to microsparitic matrix (XPL); (D) Bone fragments embedded in micritic cement and microcrystalline quartz in the upper part (XPL). 


\subsection{Mineralogy}

The two phosphatic composite samples were mineralogically identified by X-ray diffraction (XRD) analysis (Figs. 6 and 7). XRD patterns show the dominance of the diagnostic peaks of calcite, francolite, gypsum and quartz. Bassanite, a hemihydrated form of calcium sulfate $\left[2 \mathrm{CaSO}_{4} \cdot\left(\mathrm{H}_{2} \mathrm{O}\right)\right]$, is detected as major constituent in the lower composite phosphatic sample. This mineral is a lowtemperature dehydration product after gypsum due to aridity (Troev et al., 1994). Minor constituents are the iron sulphate minerals jarosite $\left[\mathrm{KFe}_{3}\left(\mathrm{SO}_{4}\right)_{2}(\mathrm{OH})_{6}\right]$ and siderotil
$\left[\mathrm{FeSO}_{4} \cdot 5\left(\mathrm{H}_{2} \mathrm{O}\right)\right]$. Iron sulphate minerals were detected by Mössbauer spectroscopy in the Maghara coal in Northern Sinai and attributed to weathering of pyrite (Eissa et al., 1992). So, the presence of iron sulphate minerals in the studied phosphatic rocks could refer to oxidation of a nearby source of organic matter enriched in pyrite. Francolite is carbonate-fluorapatite mineral $\left[\mathrm{Ca}_{5}\left(\mathrm{PO}_{4}, \mathrm{CO}_{3}\right)_{3} \mathrm{~F}\right]$, shows very sharp and narrow peaks at its typical peak positions reflecting high crystallinity and absence of isomorphous substitutions. This type of apatite (francolite) is the main variety in marine phosphorites on a global scale (McConnell, 1973).

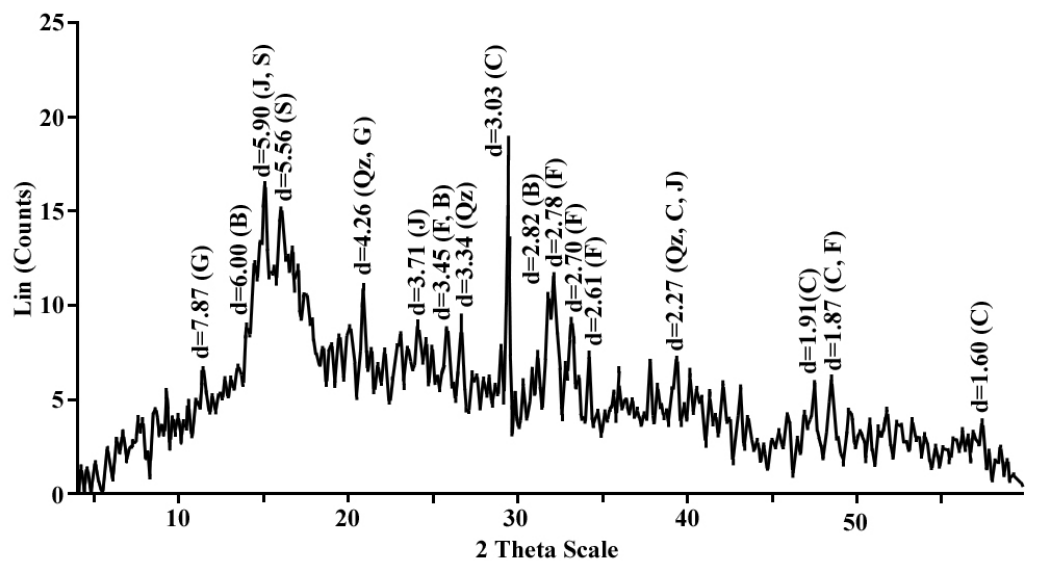

Fig. 6: XRD pattern of the lower phosphatic beds $(B=B$ assanite, $C=$ Calcite, $F=$ Francolite, $G=$ Gypsum, $\mathrm{Qz}=\mathrm{Quartz}, \mathrm{J}=$ =arosite and $\mathrm{S}=$ Siderotil); $\mathrm{d}$-spacing of major peaks are indicated.

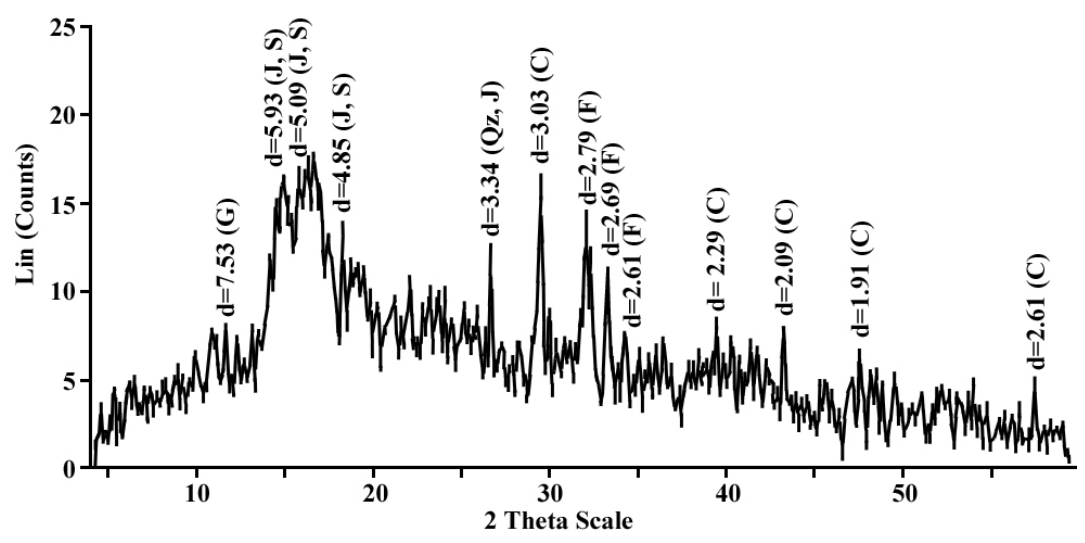

Fig. 7: XRD pattern of the upper phosphatic beds $(C=$ Calcite, $F=$ Francolite, $G=$ Gypsum, Qz=Quartz, $\mathrm{J}=$ Jarosite and $\mathrm{S}=$ Siderotil); $\mathrm{d}$-spacing of major peaks are indicated.

\subsection{Scanning electron microscope study}

SEM images and EDX spectra of the analyzed phosphatic samples are shown in (Fig. 8). They demonstrate that the major elements are $\mathrm{U}, \mathrm{V}$ and $\mathrm{K}$, which are the main constituents of carnotite mineral $\left[\mathrm{K}_{2}\left(\mathrm{UO}_{2}\right)_{2}\left(\mathrm{VO}_{4}\right)_{2} \cdot 3 \mathrm{H}_{2} \mathrm{O}\right]$. The associating minor amounts of $\mathrm{Ca}, \mathrm{P}, \mathrm{S}$ and $\mathrm{Si}$ are acquired from the calcite, gypsum, quartz and phosphatic substrate materials. Carnotite occurs on grain boundaries in cavities and exhibits maximum dissemination in zones of high porosity. Dongarra (1984) stated that this mode of occurrence could refer to carnotite precipitation from shallow groundwater or meteoric water enriched in uranyl and vanadate ions. The vanadate ions are highly effective precipitant for uranyl ions as insoluble uranyl vanadate (Dongarra, 1984). 
Journal of Environmental Sciences, 2018; Vol. 47, No. 1-2 :23-35
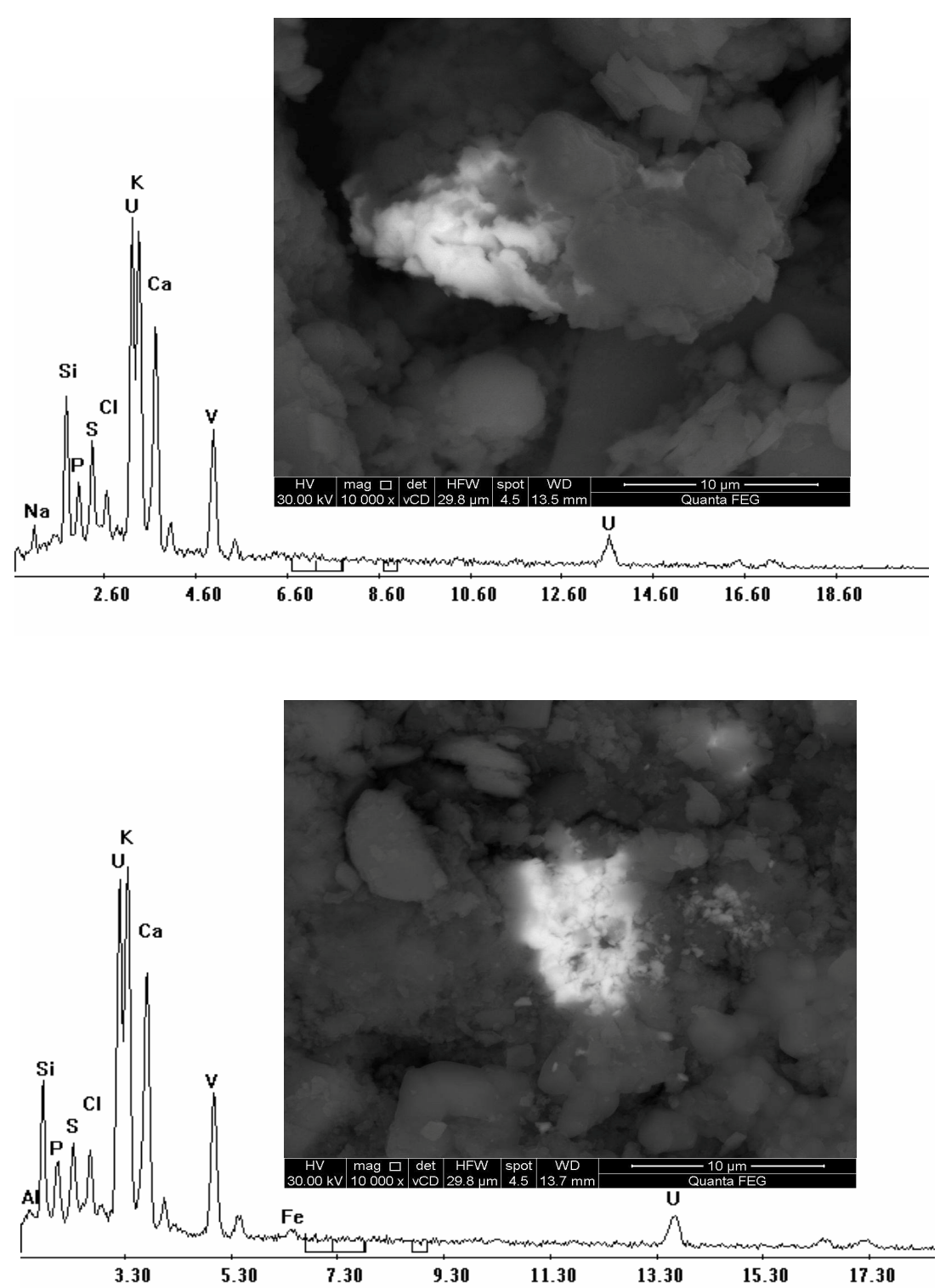

Fig. 8: SEM backscattered electron images and EDX spectra characterizing carnotite (bright) occurrence as flakes and aggregates on grain boundaries within cavities.

\subsection{Radioactivity and uranium migration}

The activity concentrations of the radionuclides ${ }^{238} \mathrm{U},{ }^{235} \mathrm{U}$, ${ }^{234} \mathrm{U},{ }^{230} \mathrm{Th},{ }^{226} \mathrm{Ra},{ }^{214} \mathrm{~Pb},{ }^{214} \mathrm{Bi},{ }^{210} \mathrm{~Pb},{ }^{232} \mathrm{Th}$ and ${ }^{40} \mathrm{~K}$ were measured in the studied phosphatic rocks using gamma-ray spectrometer with an HPGe detector (Table 1). Results indicate that they contain significant specific activities and concentrations of ${ }^{238} \mathrm{U}$ and its progenies. However, ${ }^{235} \mathrm{U}$ and ${ }^{232} \mathrm{Th}$ show minor activities and their contributions to natural radioactivity are relatively low. If daughter/parent radionuclide activity ratios in the decay series are found not to equal unity, then the equilibrium state has been disturbed, probably by meteoric or groundwater transport of radionuclides into or away from the rock. The specific activities of ${ }^{238} \mathrm{U}$ are slightly higher than that of their daughters in the $\mathrm{U}$ decay series except of ${ }^{226} \mathrm{Ra}$. The activity ratios of the long-lived isotopes ${ }^{234} \mathrm{U} /{ }^{238} \mathrm{U}$ and ${ }^{230} \mathrm{Th} /{ }^{238} \mathrm{U}$ are nearly around unity or show little deviation, which could indicate secular equilibrium state within a conservative analytical error $( \pm 10 \%)$. It is worth to mention that, in closed geological systems the nuclides ${ }^{238} \mathrm{U}_{-}{ }^{234} \mathrm{U}^{230} \mathrm{Th}$ attain radioactive equilibrium after $\sim 1.7 \mathrm{Ma}$ (Smellie et al., 1986).

Nevertheless, the daughter/parent activity ratios of ${ }^{226} \mathrm{Ra} /{ }^{238} \mathrm{U}$ in the studied phosphatic rocks show notable disequilibrium state where ${ }^{226} \mathrm{Ra}$ shows significant excess amount relative to ${ }^{238} \mathrm{U}$. This is probably due to active adsorption of ${ }^{226} \mathrm{Ra}$ during weathering processes (Burnett et al., 1988) or the outward migration of ${ }^{238} \mathrm{U}$ (El-Aassy et al., 2011). Also, the studied rocks show ${ }^{210} \mathrm{~Pb} /{ }^{226} \mathrm{Ra}$ activity ratios much less than unity probably due to great radon loss. Accordingly, these ratios reflect the intensive weathering 
effects leading to re-distribution of uranium decay-series isotopes in the studied phosphatic rocks. In the same respect, the activity ratio ${ }^{238} \mathrm{U}^{235} \mathrm{U}$ of the two major isotopes of uranium is constant in natural uranium occurrences with a value of 137.88 as assumed by Farley et al. (2002). The present study determinations have shown that this value is 140.64 and 141.79 for the lower and upper phosphatic beds, respectively, which are seemingly convenient with the natural abundance of uranium isotopes.

The determined chemical uranium contents $(\mathrm{cU})$ of the lower and upper composite phosphatic samples are 55 and 85 ppm, respectively. Then the calculated equilibrium D-factor
(Adams and Weaver, 1958; cU/eU) values are 0.78 and 1.14, respectively. These values could indicate moderate uranium upward mobilization within the phosphatic horizon, where the upper phosphatic beds show addition of uranium young gamma-rays. From another point of view, the determined $\mathrm{P}_{2} \mathrm{O}_{5}$ contents are 15.36 and $18.01 \%$ for the studied lower and upper composite phosphatic samples, respectively. These values show close relation with the determined chemical uranium contents. Nevertheless the slight increase in the $\mathrm{P}_{2} \mathrm{O}_{5}$ content from 15.36 to $18.01 \%$ is not consistent with the rise in uranium (about 55\%) which suggests possible secondary uranium enrichment.

Table 1: Specific activities, activity ratios and equivalent concentrations of uranium (eU), thorium (eTh) and potassium (K) in Wadi El-Quseiyib phosphatic rocks.

\begin{tabular}{|c|c|c|c|c|}
\hline \multirow{2}{*}{ Radionuclide } & \multicolumn{2}{|c|}{ lower composite phosphatic sample } & \multicolumn{2}{|c|}{ upper composite phosphatic sample } \\
\hline & Activity (Bq/kg) & Eq. Conc. & Activity (Bq/kg) & Eq. Conc. \\
\hline \multicolumn{5}{|l|}{${ }^{238} \mathrm{U}$ Series } \\
\hline${ }^{238} \mathrm{U}$ & 872.00 & $70.32 \mathrm{ppm}$ & 914.30 & $73.73 \mathrm{ppm}$ \\
\hline${ }^{234} \mathrm{U}$ & 683.36 & & 892.27 & \\
\hline $230 \mathrm{Th}$ & 809.95 & & 1072.81 & \\
\hline${ }^{226} \mathrm{Ra}$ & 2647.41 & & 3064.20 & \\
\hline${ }^{214} \mathrm{~Pb}$ & 846.85 & & 839.40 & \\
\hline${ }^{214} \mathrm{Bi}$ & 842.00 & & 834.70 & \\
\hline${ }^{210} \mathrm{~Pb}$ & 734.83 & & 764.94 & \\
\hline${ }^{235} \mathbf{U}$ & 40.06 & $0.50 \mathrm{ppm}$ & 41.69 & $0.52 \mathrm{ppm}$ \\
\hline \multicolumn{5}{|l|}{${ }^{232}$ Th Series } \\
\hline${ }^{228} \mathrm{Ac}$ & 22.44 & & 23.10 & \\
\hline${ }^{208} \mathrm{Tl}$ & 22.61 & & 22.91 & \\
\hline Average & 22.53 & $5.58 \mathrm{ppm}$ & 23.00 & $5.69 \mathrm{ppm}$ \\
\hline${ }^{40} K$ & 33.75 & $0.11 \%$ & 21.35 & $0.07 \%$ \\
\hline $\mathrm{P}_{2} \mathrm{O}_{5}$ & \multicolumn{2}{|c|}{$15.4 \%$} & \multicolumn{2}{|c|}{$18.0 \%$} \\
\hline $\mathrm{cU}$ & \multicolumn{2}{|c|}{$55 \mathrm{ppm}$} & \multicolumn{2}{|c|}{$85 \mathrm{ppm}$} \\
\hline $\mathrm{cU} / \mathrm{eU}$ & \multicolumn{2}{|c|}{0.78} & \multicolumn{2}{|c|}{1.14} \\
\hline${ }^{238} \mathrm{U} /{ }^{235} \mathrm{U}$ & \multicolumn{2}{|c|}{140.64} & \multicolumn{2}{|c|}{141.79} \\
\hline${ }^{234} \mathrm{U} /{ }^{238} \mathrm{U}$ & \multicolumn{2}{|c|}{0.784} & \multicolumn{2}{|c|}{0.976} \\
\hline${ }^{230 \mathrm{Th}} /{ }^{238} \mathrm{U}$ & \multicolumn{2}{|c|}{0.929} & \multicolumn{2}{|c|}{1.17} \\
\hline${ }^{226} \mathrm{Ra} /{ }^{238} \mathrm{U}$ & \multicolumn{2}{|c|}{3.036} & \multicolumn{2}{|c|}{3.351} \\
\hline${ }^{210} \mathrm{~Pb} /{ }^{226} \mathrm{Ra}$ & \multicolumn{2}{|c|}{0.277} & \multicolumn{2}{|c|}{0.2496} \\
\hline Exposure & \multicolumn{2}{|c|}{$47.583 \mathrm{mR} / \mathrm{hr}$} & \multicolumn{2}{|c|}{$50.195 \mathrm{mR} / \mathrm{hr}$} \\
\hline E. Dose Equivalent & \multicolumn{2}{|c|}{$1.495 \mathrm{mSv} / \mathrm{yr}$} & \multicolumn{2}{|c|}{$1.7 \mathrm{mSv} / \mathrm{yr}$} \\
\hline $\mathrm{Ra}_{\mathrm{eq}}$ & \multicolumn{2}{|c|}{$2681.89 \mathrm{~Bq} / \mathrm{kg}$} & \multicolumn{2}{|c|}{$3098.9 \mathrm{~Bq} / \mathrm{kg}$} \\
\hline
\end{tabular}




\section{Hazard indices and the environmental impact}

Of course, the natural radiation environment in the study area is influenced by the existence of phosphatic materials which could be fairly hazardous to the living Bedouin community. To assess the environmental radioactivity hazards, the measured gamma-ray radiation activity values in Becquerel per kilogram in pure dry air $(\mathrm{Bq} / \mathrm{kg})$ resulted from the naturally occurring radioactive isotopes ${ }^{238} \mathrm{U},{ }^{232} \mathrm{Th}$ and ${ }^{40} \mathrm{~K}$ together with the radionuclides into which they decay, were converted to exposure (dose) values. These values are calculated as annual effective dose equivalent (AEDE) of gamma radiation to outdoor exposure in milli-sievert per year ( $\mathrm{mSv} / \mathrm{yr}$ ) according to the relationships provided by (IAEA, 1990) and (UNSCEAR, 2000).

The calculated (AEDE) values form outdoor exposures are 1.495 and $1.7 \mathrm{mSv} / \mathrm{yr}$ for the lower and upper phosphatic beds, respectively. It is worth to mention that the world average (AEDE) value from exposure to outdoor terrestrial gamma radiation is $613.2 \mathrm{mSv} / \mathrm{yr}$, but fortunately the value in "normal" parts of the world is only $2.4 \mathrm{mSv} / \mathrm{yr}$ (UNSCEAR, 2000). However, according to the International Commission of Radiation Protection (ICRP, 2007), the appropriate annual dose limits for the public are $1 \mathrm{mSv}$ for the body, $15 \mathrm{mSv}$ for the thyroid or eyes and $50 \mathrm{mSv}$ for the skin. Nevertheless, the exposure due to gamma-radiation could also be defined in terms of the radium equivalent activity $\left(\mathrm{Ra}_{\mathrm{eq}}\right)$, which is a widely used index for assessing radiation health hazards (Beretka and Mathew, 1985). The maximum value of $\left(\mathrm{Ra}_{\mathrm{eq}}\right)$ must be less than $370 \mathrm{~Bq} / \mathrm{kg}$, in order to keep the annual external absorbed dose safe (UNSCEAR, 2000). The calculated values of $\left(\mathrm{Ra}_{\mathrm{eq}}\right)$ are 2681.89 and $3098.9 \mathrm{~Bq} / \mathrm{kg}$ for the lower and upper phosphatic beds, respectively, which are higher than the maximum recommended limit. Accordingly, it could be stated that although the estimated effective dose equivalent to public is below the recommended limits but the equivalent radium activity and the expected coincided radon gas emanation renders the area of phosphatic exposures classified as unsafe area for prolonged public activities.

\section{Discussion}

The present petrographical and mineralogical investigations revealed that the studied phosphatic beds of the Sudr Chalk of Wadi El-Quseiyib are mostly similar in texture and composition to other Egyptian phosphorites elsewhere (cf. El Kammar and El Kammar, 2002). In addition, the confinement of U-content variation to a limited tens of parts per million (3-177 ppm, with an average of $44 \mathrm{ppm}$ ), could suggest rather consistent depositional environment for the Egyptian phosphorites. This moderate variation in U-content could be related to several factors, among them, the duration of direct contact with sea water, the possible diagenetic chemical weathering processes, and the paleotopographic position concerning the proximity to sources of clastic input
(Slansky, 1986). In general terms, the deposition of chalk of the Sudr Chalk has been considered to reflect stable depositional conditions over long time intervals during the Late Cretaceous. However, facies shifts represented by the presence of several phosphatic beds in the upper part of the Markha Member could indicate shallowing in the sea floor. Generally, the phosphate sections of Sinai are dominated by an alternation of chalk and cherty sediments and show striking similarities both with the Duwi Fm. Of the Red Sea region and the Mishash Fm. Of Negev (Germann et al., 1987).

The identification and characterization of carnotite in the studied phosphatic rocks for the first time in East Central Sinai phosphatic rocks could provide some constraints on the depositional environment and post-depositional weathering history. Understanding the mechanisms of formation of carnotite in the studied phosphatic rocks is important with respect to their implications in further exploration for similar deposits. The accompanying silica provides evidence on the syn-depositional flourishing microbial activity leaving behind organic matter that easily oxidized in shallow water environment. Decomposition of such organic matter could provide the source of vanadium and pyrite, which oxidized upon weathering to leave the determined iron sulphate minerals (Telfeyan et al., 2017). Uranium could be also provided by oxidation of $\mathrm{U}^{4+}$ in the phosphatic materials to form the more mobile $\mathrm{U}^{6+}$ followed by leaching.

Carnotite is generally formed in highly oxidizing and near neutral environment, and is readily soluble in acid and alkaline solutions (Bowell et al., 2011). It is well established that most near-surface groundwater dissolved carbonates combine with the dissolved uranium to form uranyl carbonate complexes (Langmuir, 1978). Most likely, high carbonate fluids are responsible for mobilization of uranium as $\mathrm{U}^{6+}$ and redeposition in response to changes in $\mathrm{pH}$-Eh physicochemical conditions due to de-complexing of uranyl carbonates in pore waters of higher salinity (Rose et al., 1979; Gilat, 1980, Bowell and Davies, 2017). Evaporative controls, common ion effect and capillary driven diffusion mechanisms have been invoked (Cameron et al., 2002). Consequently, a supergene hypothesis depending on the slow upward moving groundwater or percolating meteoric water undergoing chemical and redox changes under the influence of evaporation allowing for near-surface precipitation of carnotite. So, the present authors believe that evaporative concentration of $\mathrm{U}, \mathrm{V}$ and $\mathrm{K}$ from circulating meteoric water might be the supposed mechanism that responsible for the genesis of carnotite in the present study area. In addition, the observed uranium depletion in the lower phosphatic beds and relatively enrichment in the upper beds is another criterion which supported the suggested mechanism.

Hassan et al. (1983) reported secondary uranium mineralization occurrences in extensive areas in Egypt. They concluded that phosphates cropping out in highlands that 


\section{Journal of Environmental Sciences, 2018; Vol. 47, No. 1-2 :23-35}

drained into depressions such as at the Bahariya Oasis were responsible for the formation of the low-lying surficial uranium deposits. Also, uranium was supposed to be leached out of the Negev phosphorites and migrated towards the Dead Sea Rift Valley and concentrated in pedogenic layers (Gross and Ilani, 1987; Ilani and Strull, 1989; Ilani et al., 2006). Such surficial uranium concentrations are widespread in central and northern Jordan and in Syria where pedogenic layers like calcrete and gypcrete acted as lithological trap and fixed uranium (Dill, 2011).

This review of facts could be helpful in delineating additional potential areas containing surficial uranium occurrences for further exploration. Physiographically, Wadi El-Quseiyib area is a dry valley, which can be divided into the eastern fan delta and coastal plains, and the western hill ranges with exposed phosphatic rocks, dissected by the upper valley tributaries. The restricted alluvial plains along the dry valley that fed by temporary streams and groundwater seepage could be considered as the prospective targets for such exploration processes.

\section{Conclusions}

Microscopic investigation, XRD, SEM/EDX and gammaray spectrometry with HPGe detector have been used in studying the phosphatic rocks of the Sudr Chalk cropping out at Wadi El-Quseiyib area, East Central Sinai. Petrographically, the collophane pellets and bone fragments represent the main phosphatic constituents which suffered diagenetic alteration through dissolution and precipitation of micrite, gypsum and microcrystalline quartz. Mineralogically, the carbonate fluorapatite (francolite) is the only recorded phosphatic mineral. The recorded non-phosphatic minerals are calcite, gypsum, bassanite, quartz and some jarosite and siderotil.

The SEM images and EDX spectra of the phosphatic samples proved the occurrence of carnotite $\left[\mathrm{K}_{2}\left(\mathrm{UO}_{2}\right)_{2}\left(\mathrm{VO}_{4}\right)_{2} .3 \mathrm{H}_{2} \mathrm{O}\right]$; for the first time in the phosphatic beds in east central Sinai as fine aggregates disseminated on the constituent grain boundaries. Evaporative concentration of $\mathrm{U}, \mathrm{V}$ and $\mathrm{K}$ from meteoric waters might be the responsible process for the precipitation of carnotite. The average of the determined uranium content is $70 \mathrm{ppm}$. It is suggested that the uranium is leached out from the phosphatic materials and reprecipitated as secondary uranium mineral in open pores by circulating meteoric water.

The widely accepted perspective of the genesis of uranium in phosphorites either as incorporation in the crystal lattice of apatite or adsorbed on the accompanying organic matter and/or iron oxyhydroxides is being contributed by the role of the newly formed secondary uranium minerals, which could be considered as a potential uranium resource. The relatively low uranium content generally detected in the studied phosphatic beds compared with the relatively high content of its daughter isotopes suggests uranium outward migration. Further exploration is recommended to delineate possible surficial traps suitable for uranium fixation in the nearby lowlying areas. The calculated annual effective dose equivalent values (AEDE) are 1.495 and $1.7 \mathrm{mSv} / \mathrm{yr}$ for the lower and upper phosphatic beds, respectively. The calculated equivalent activity values of $\left(\mathrm{Ra}_{\mathrm{eq}}\right)$ are 2681.89 and $3098.9 \mathrm{~Bq} / \mathrm{Kg}$ for the lower and upper phosphatic beds respectively. Accordingly, although the estimated (AEDE) to the public is below the recommended limits, but the equivalent radium activity and the expected coincided radon gas emanation renders the study area classified as unsafe for prolonged public activities.

\section{Acknowledgements}

The authors are most grateful to Dr. Nikola Rizk Guirgues (retired general director, Academy of scientific research and technology) for his help in providing the phosphatic samples.

\section{References}

Adams, J.A. and Weaver, C.E. (1958): Thorium-to-uranium ratios as indicators of sedimentary processes: Example of concept of geochemical facies. AAPG Bull., 42 (2): $387-430$.

Altschuler, Z.S. (1980): the geochemistry of trace elements in marine phosphorites, Part 1: Characteristic abundances and enrichment., SEPM. Spec Publ., V.29, pp 19-30.

Beretka, J. and Mathew, P. J. (1985): Natural radioactivity of Australian building materials, industrial wastes and byproducts. Health and Physics, 48: 87-95.

Bowell, R.J. and Davies, A.A. (2017): Assessment of supergene uranium-vanadium anomalies, Meob Bay deposit, Namibia. Geochemistry: Exploration, Environment, Analysis, 17 (2): 101-112.

Bowell, R.J., Grogan, J., Hutton-Ashkenny, M., Brough, C., Penman, K. and Sapsford, D.J. (2011): Geometallurgy of uranium deposits. Minerals Engineering, 24 (12): 1305-1313.

Burnett, W. C., Baker, K. B., Chin, P. A., McCabe, W. and Ditchburn, R. (1988): Uranium-series and AMS ${ }^{14} \mathrm{C}$ studies of modern phosphatic pellets from Peru shelf muds. Marine Geology, 80: 215-230.

Butt, C.R., Mann, A.W. and Horwitz, R.C. (1984): Regional setting, distribution and genesis of surficial uranium deposits in calcretes and associated sediments in Western Australia. In: Surficial Uranium Deposits, IAEA-TECDOC-322, IAEA, Vienna, pp. 121-127. 
Cameron, E.M., Leybourne, M.I. and Kelley, D.L. (2002): Exploring for deeply covered mineral deposits: formation of geochemical anomalies at the Spence copper porphyry deposit, Chile. Geology, 30: 10071010 .

Carlisle, D. (1984): Surficial uranium occurrences in relation to climate and physical setting. In: Surficial Uranium Deposits, IAEA-TECDOC 322, IAEA, Vienna, pp. 2535 .

Chinnaesakki, S., Bara, S.V., Sartandel, S.J., Tripathi, R.M. and Puranik, V.D. (2012): Performance of HPGe gamma spectrometry system for the measurement of low level radioactivity. Jour. Radioanal. Nucl. Chem., 294: 143-147.

CONOCO Coral and EGPC (1987): Geological map of Egypt, South Sinai sheet, scale 1:500,000, Cairo, Egypt.

Dall'Aglio, M., Gragnani, R. and Locardi, E. (1974): Geochemical factors controlling the formation of the secondary minerals of uranium. In: Formation of Uranium Ore Deposits, IAEA-SM-183/21, IAEA, Vienna, pp. 33-48.

Dill, H.G. (2011): A comparative study of uranium-thorium accumulation at the western edge of the Arabian Peninsula and mineral deposits worldwide. Arab. Jour. Geosci., 4: 123-146.

Dongarra, G. (1984): Geochemical behavior of uranium in the supragene environment. In: B. De. Vivo, F. Ippolito, G. Capaldi and P.R. Simpson (Eds.), Uranium geochemistry, mineralogy, geology, exploration and resources. The Institution of Mining and Metallurgy, London, pp. 18-22.

Eissa, N.A., Sheta, N.H. and Ahmed, M.A. (1992): Application of Mössbauer spectroscopy for: (1) characterization of Egyptian Maghara coal; (2) evaluating the efficiency of different methods for coal desulphurization. Hyperfine Interactions, 70: 941-944.

El Aassy, I.E. (1992): Studies on the geology and radioactivity of phosphorites occurrence in Taba area, Eastern Sinai, Egypt. The Int. Symp. on Phosphorites, Feb. 22-24, Assiut Univ, Egypt, 21 p.

El Aassy,I.E., El Galy,M.M., Nada,A.A., El Feky, M. G., Abdel Maksoud,T.M., Talaat,S.M. and Ibrahim,E. M. (2011): Effect of alteration processes on the distribution of radionuclides in uraniferous sedimentary rocks and their environmental impact, southwestern Sinai, Egypt. Jour. Radioanalytical and Nuclear Chemistry, 289(1):173-184.

El Kammar, A.M. and El Kammar, M.M. (2002): On the trace elements composition of the Egyptian phosphorites: A new approach. Proc. 6th Int. Conf. Geol. Arab World, Cairo Univ., pp. 227-244.

Farley, K.A., Kohn, B.P. and Pillans, B. (2002): The effects of secular disequilibrium on (U-Th)/He systematics and dating of Quaternary volcanic zircon and apatite. Earth Planet. Sci. Letters, 201 (1): 117-125.

Fleurance, S., Cuney, M., Malartre, F. and Reyx, J. (2013): Origin of the extreme polymetallic enrichment $(\mathrm{Cd}, \mathrm{Cr}$, Mo, Ni, U, V, Zn) of the Late Cretaceous-Early Tertiary Belqa Group, central Jordan. Palaeogeography, Palaeoclimatology, Palaeoecology, 369: 201-219.

Flexer, A. and Honigstein, A. (1984): The Senonian succession in Israel; lithostratigraphy, biostratigraphy and sea level changes. Cretaceous Research, 5: 303312 .

Germann, K., Bock, W.-D., Ganz, H., Schröter, T. and Tröger, U. (1987): Depositional conditions of late Cretaceous phosphorites and black-shales in Egypt. Berliner geowiss. Abh., Vol. 75.3A, pp. 629-668.

Ghorab, M.A. (1961): Abnormal stratigraphic features in Ras Gharib oil field. - Proc. 3rd Arab Petroleum Congress, 2, pp. 1-10, Alexandria, Egypt.

Gilat, A. (1980): Hydrothermal barite mineralization and anomalous metal contents associated with faulting, Judean Desert. 5th Conf. Min. Eng., Mining Industry in Israel, pp. 79-85.

Gross, S. and Ilani, S. (1987): Secondary uranium minerals from the Judean Desert and the northern Negev, Israel. Uranium, 4: 147-158.

Guirgues, N.R. (2005): Geological and geochemical studies on some phosphate exposures, East-Central Sinai, Egypt. Ph.D. Thesis, Fac. Sci., Mansoura Univ., Egypt, 237 p.

Hassan, M.A., Hussein, H.A. and Hashad, A.H. (1983): Some geological concepts in uranium exploration in Egypt. Jour. African Earth Sci., 1 (3-4), Abstract, p. 359.

Helmdach, F., Khoury, H., and Meyer, J. (1985): Secondary uranium mineralization in the Santonian-Turonian, near Zarqa, north Jordan, Dirasat, 12: 105-111.

Hussein, H.A., El Aassy, I.E., Mahdy, M.A., Dabbour, G.A., Morsy, M.A. and Mansour, M.G. (1996): Uranium traps in the phosphate bearing Sudr Chalk, in Northeastern Sinai, Egypt. Proc. Third Arab Conf. on the Peaceful Uses of Atomic Energy, Damascus 9-13 Dec. 1996, AAEA, pp. 357-372.

IAEA (1990): The use of gamma-ray data to define the natural radiation environment. IAEA-TECDOC-566, IAEA, Vienna, 48 p. 
ICRP (2007): The 2007 recommendations of the International Commission on Radiological Protection. ICRP publication 103, Annals of the ICRP, Vol. 37, No. 2-4, $332 \mathrm{p}$.

Ilani, S. and Strull, A. (1989): Uranium mineralization in the Judean Desert and in the northern Negev, Israel. Ore Geol. Rev., 4: 305-314.

Ilani, S., Minster, T., Kronfeld, J. and Even, O. (2006): The source of anomalous radioactivity in the springs bordering the Sea of Galilee. Israel. Jour. Environ. Res., 85: 137-146.

Issawi, B., El-Hinnawi, M., Francis, M. and Mazhar, A. (1999): The Phanerozoic geology of Egypt: A geodynamic approach. Geol. Surv. Egypt, Sp. Publ. 76, $472 \mathrm{p}$.

Khater, A.E., Galmed, M.A., Nasr, M.M. and El-Taher, A. (2016): Uranium and rare earth elements in Hazm ElJalamid phosphate, Saudi Arabia: Concentrations and geochemical patterns comparison. Environ. Earth Sci., 75: $1261-1272$.

Kora, M. and Genedi, A. (1995): Lithostratigraphy and facies development of Upper Cretaceous carbonates in east central Sinai, Egypt. Facies, 32: 223-236.

Langmuir, D. (1978): Uranium solution-mineral equilibrium at low temperatures with application to sedimentary ore deposits. Geochim. Cosmochim. Acta, 42: 547-569.

Mann, A.W. and Deutscher, R.L. (1978): Genesis principles for the precipitation of carnotite in calcrete drainages in Western Australia. Economic Geology, 73 (8): 1724-1737.

McConnell, D. (1973): Apatite: Its crystal chemistry, mineralogy utilization and geologic and biologic occurrences. Springer, New York, 111 p.
Nash, J.T., Granger, H.C. and Adams, S.S. (1981): Geology and concepts of genesis of important types of uranium deposits. Economic Geology, $75^{\text {th }}$ Anniversary Volume, pp. 63-116.

Roessler, C.E. (1990): Control of radium in phosphate mining, beneficiation and chemical processing, Vol 2, Technical Report Series No. 310, IAEA, Vienna, 269 p.

Rose, A.W., Hawkes, H.E. and Webb, J.S. (1979): Geochemistry in mineral exploration. Second Ed., Academic Press, London, 657 p.

Slansky, M. (1986): Geology of Sedimentary Phosphates. North Oxford Academic, London, $210 \mathrm{p}$.

Smellie, J.A.T., MacKenzie, A.B. and Scott, R.D. (1986): An analogue validation study of natural radionuclide migration in crystalline rocks using uranium-series disequilibrium studies. Chemical Geology, 55: 233254.

Telfeyan, K., Breaux, A., Kim,J., Cable,E., J., Kolker, S., A., Grimm, A., D. and Johannesson,H., K., (2017): Arsenic, Vanadium, Iron and manganese biogeochemistry in a deltaic wetland, southern Louisiana, USA. Marine Chemistry 192: 32-48.

Troev, T., Petkov, M., Alemany C. and Serna J. (1994): Dehydration products of gypsum: Positron annihilation and dielectric measurements. Jour. Materials Sci., 29 (4): 865-869.

UNSCEAR (2000): The United Nations Scientific Committee on the effects of atomic radiation. Sources and effects of ionizing radiation, Report to the General Assembly. United Nations, New York.

Vogel, A.I. (1989): Textbook of quantitative chemical analysis. Fifth Ed., Longman scientific \& Technical, London, $877 \mathrm{p}$. 


\section{المذص العربي}

تواجد الكارنوتيت في النطاق الفوسفاتي بطباشير سدر، وادي القصيب، شرق وسط سيناء،

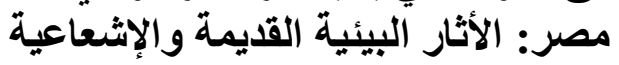

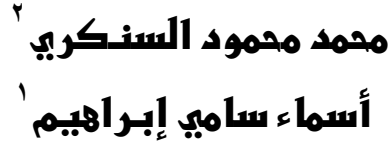

r أسسماء سامي إبراهيهم

\section{أمين مصطفي غبثذ'

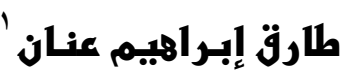

$$
\text { ' قسم الجيولوجيا، كلية العلوم، جامعة المنصورة، مصر }
$$

لوحظت محتو يات متمايزة من اليور انيوم فى رواسب الفوسفات المنتمية لطباثشير سدر بو ادى القصيب الو اقع فى شرق وسط سيناء. وقد تم إجر اء در اسات ميكروسكوبية إكتملت بالدر اسة بو اسطة الميكروسكوب الإلكترونى الماسح و التى أكدت تو اجد معدن

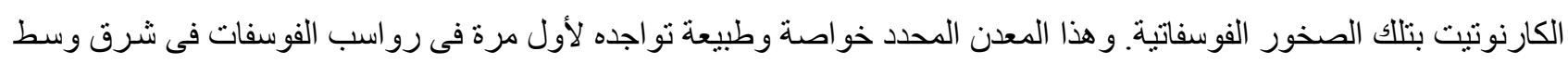

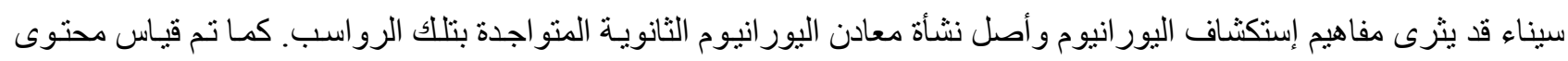

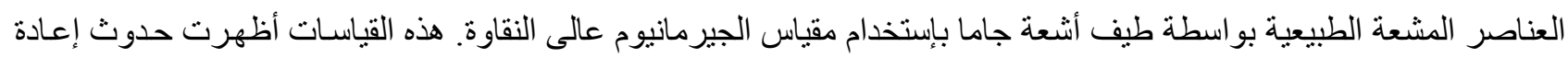
توزيع لليور انيو و النظائر الناتجة عن تحلله فى الصخور الحاوية له بسبب حدوث عمليات التغير والتحول اللاحقة للتكوين. كمـا أظهرت الدر اسـة البتروجر افيـة أن رواسب الفوسفات في و ادي القصيب تتكون من حبيبـات الكللوفـان وبعض العظـام

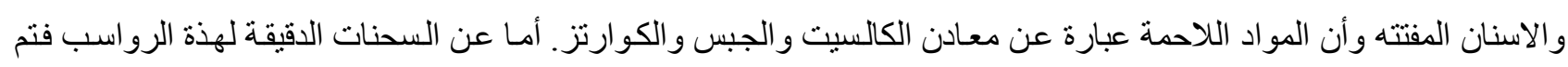

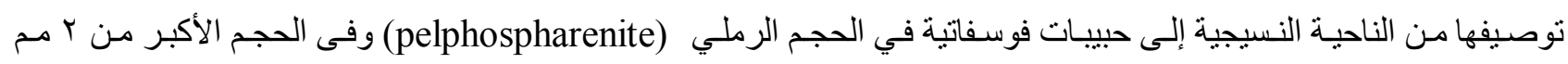
(pelphospharudite)

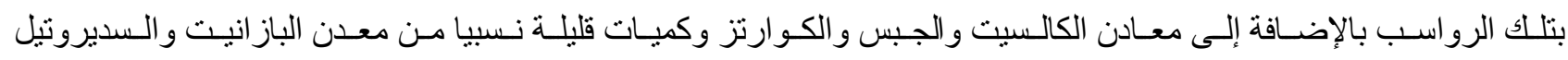

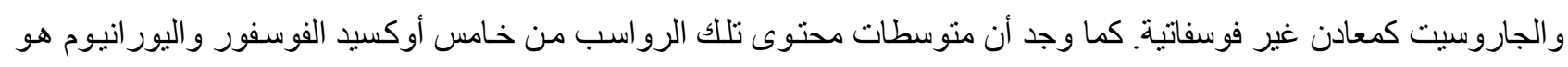

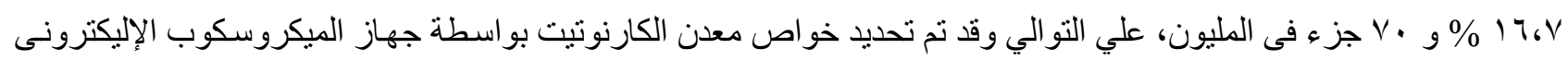

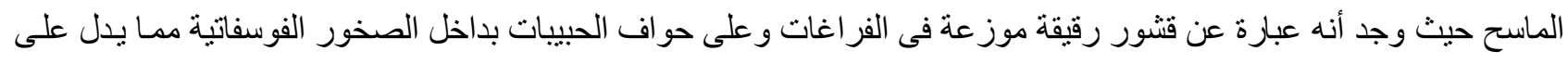

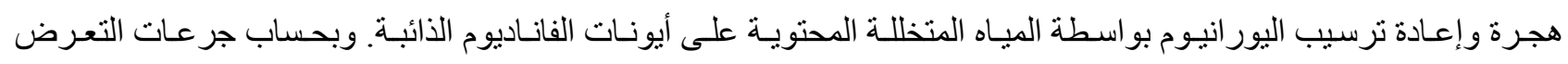
الاشعاعية الفعالة السنوية المكافئة لطبقات الفوسفات السفلية والعلوية وجد أنها تساوى 1.495و 1.4 1.7 مللي سيفرت في في السنة على

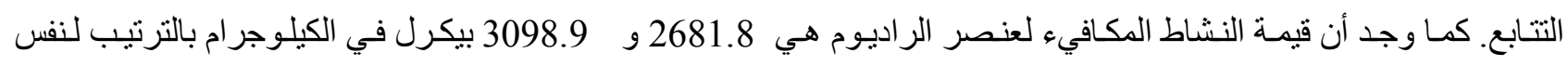

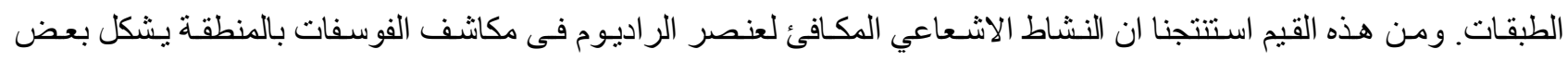
الخطورة عند التعرض له لفترات طويلة. 


\title{
Journal of Environmental Sciences
}

\section{JOESE 5}

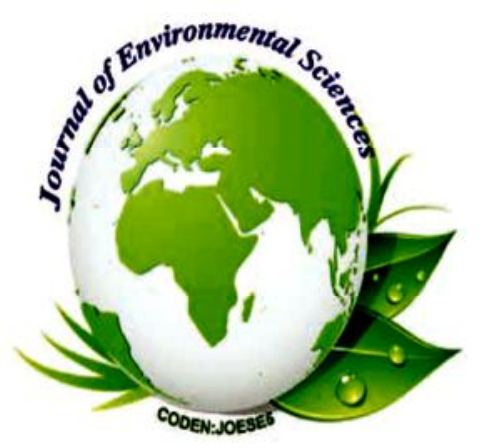

Occurrence of Carnotite in the Phosphatic horizon of the Sudr Chalk, Wadi El-Quseiyib, East Central Sinai, Egypt:

Paleoenvironmental and Radioactivity Implications

\author{
Amin M. Gheith ${ }^{1}$, Mohamed M. EI Sankary ${ }^{2}$, Tarek I. Anan ${ }^{1}$ and Asmaa S. Ibrahim ${ }^{1}$ \\ ${ }^{1}$ Department of Geology, Faculty of Science, Mansoura University, Mansoura, Egypt \\ ${ }^{2}$ Nuclear Materials Authority, El Maadi, Cairo, Egypt
}

\section{Reprint}

Volume 47, Number 1-2 : 23-35

(2018) 